\title{
INTELLECTUALLY-INNOVATIVE CLUSTERS AS THE BASIS OF INDUSTRIAL POTENTIAL DEVELOPMENT
}

\author{
Oleg Kuzmin ${ }^{1}$, Natalia Stanasiuk ${ }^{2}$, Olexandra Vivchar ${ }^{3}$
}

\begin{abstract}
The purpose of the paper is the formation of a new type of industrial clusters as a modern basis for the spatial development of industrial potential. Methodology. The methodological basis of the article is methods of scientific cognition, which allow revealing the essence of the clustering process. In particular, the following methods are used: fuzzy cluster analysis - for the construction of intellectual-innovative industrial clusters; grouping - for the determination of types of intellectually-innovative industrial clusters; systematization - for studying foreign experience; abstraction - for the formation of theoretical generalization and conclusions. Results. Foreign experience of effective cluster structures creation in the industrial sector of the economy is analysed and the necessity of establishing cooperation between education, science, and business structures is proved. By means of the indistinct S-averages method, taking into account indicators of development of industrial potential intellectual and innovative components, measures matrices of Ukraine's administrative-territorial units belonging to four clusters have been developed, each of the clusters differs by the development level of corresponding component (very high, high, average, and low). On the basis of the achieved results, the conclusion is made that it is necessary to create intellectually-innovative industrial clusters in which administrative-territorial units with the high development level of intellectual potential will act as a catalyst of innovative development of the industrial potential. The role of the state is defined as an activator of establishing cooperation between education, science, and business structures. It was offered to work out the conception of cluster policy and distinguish pilot projects in the industrial sector of the economy taking into account modern directions of the global economic development. Global practical experience of stimulation of industrial potential innovative development is generalized on a cluster basis. With the aim to institutionalize the activity of intellectually-innovative industrial clusters creation, it is offered to use a cluster passport with the introduction of such sections as innovativeness of a project and relevance to the strategic targets of the state economic development. Practical implications. Practical implications are related to the possibility of establishing an effective dialogue not only between business structures but also with educational establishments, scientific institutions, and government bodies. Value/originality lies in the development of a typology of industrial clusters taking into account indicators of development of intellectual and innovative components and the formation on this basis of the cluster concept of the development of industrial potential.
\end{abstract}

Key words: cluster, innovations, innovative development, industrial potential, intellectual component.

JEL Classification: O31, F63

\section{Introduction}

Under the condition of the current situation of protracted financial-economic crisis in Ukraine, cluster organization of industrial production is considered to be a stimulator of transition to the innovative development model. The cluster approach to the industrial potential development will promote the increase of its competitiveness due to establishing an

\footnotetext{
Corresponding author:

${ }^{1}$ Lviv Polytechnic National University, Ukraine.

E-mail: oleg.y.kuzmin@lpnu.ua

ORCID: https://orcid.org/0000-0002-6014-6437

${ }^{2}$ Lviv Polytechnic National University, Ukraine.

E-mail: ovssns@ukr.net

ORCID: https://orcid.org/0000-0002-6885-9431

${ }^{3}$ Lviv Polytechnic National University, Ukraine.

E-mail: 63vivchar@gmail.com
}

effective dialogue not only between business structures but also with educational establishments, scientific institutions, and government bodies. We should note that, according to the research conducted by the international agency Bloomberg in 2016, Ukraine is in the list of top-50 countries of the world by the innovative index value and on the $5^{\text {th }}$ place by the level of educational component development (Bloomberg 
Innovation Index, 2016). Creation of Single European scientific space still remains an urgent issue nowadays, which will allow creating favourable conditions to carry out scientific researches and increase the effectiveness of scientific developments.

Creation of intellectually-innovative industrial clusters in Ukraine will get the knowledge resource closer to enterprise structures, make the transfer of knowledge faster, and provide a gradual transition to the development of industrial potential on the innovative basis. To achieve this purpose, there are the following tasks: to study foreign experience of effective cluster structures creation in the industrial sector of the economy; to carry out clusterization of administrative-territorial units of Ukraine by the indexes of development of industrial potential intellectual and innovative components; to work out the conceptual principles of intellectuallyinnovative industrial clusters creation.

\section{Foreign experience of cluster creation}

It should be noted that A. Marshal was among the first who defined advantages of establishing network collaboration between economic agents, examining the industrial regions of Great Britain (industrial agglomerations) (2008). Ideas as to advantages of network collaboration became the basis for cluster theory development. According to M. Porter, a cluster unites not only interdependent companies but also scientific research institutions, higher educational establishments, and other organizations that complement each other (1990).

In European countries, cluster development of industrial potential is one of the conditions of competitiveness growth of national economy. In particular, Strategy of industry competitiveness growth on cluster basis was worked out in Slovenia. The core documents of cluster policy development in the mentioned countries are the European Regional Charter and the Cluster Initiative Greenbook.

Successful operation of industrial clusters is determined by maintaining a stimulation policy aimed at establishing cooperation between research institutions, universities, and industrial sector. The example of such successful collaboration is Silicon Valley in the USA, establishing partnership relations between Stanford University and hi-tech enterprises in the field of electronics became the basis for its development.

As a result, the level of economic development of the region rose considerably, new workplaces appeared, and the level of innovativeness of industrial projects increased. The launch of the plant producing electronic computing machines in 1956 became a significant result of the introduction of scientific developments in industrial production. Today, clusterization is the basis for defining priorities of innovative policy and working out investment-innovative programs in the region.
Thus, the intellectual potential is the basis for innovative development of the industrial potential, and its accumulation will become the key factor for the transition to the innovative economy. Therefore, higher educational establishments and scientific research institutions must occupy a central position in modern innovative clusters. In this case, the role of academic establishments is to train proper specialists, and upgrade the employees' qualification, the task of scientific institutions is to carry out scientific researches focused on market needs. Taking into account foreign experience, colleges must be located near the sites of industrial enterprises in order to provide practical part of the educational process, and universities location should be in the centre of development of a certain type of industrial activity in order to ensure the solving of current and strategic development issues (Druhov, 2012). There is no single opinion as to scientific research institutions because scientific structural units of universities can carry out scientific researches. The growth of their activity will lead to developing a new type of research universities able to become centres of cluster formation.

In E. Mansfield's opinion, scientific researches of the applied nature are the basis of successful economic development of a country, and improvement of national economic competitiveness (1998). H. Etzkowitz and L. Leydesdorff consider the development of "triple spiral" between a production sector (enterprise structures), intellectual infrastructure (research institutions, universities), and management bodies (state authorities, local self-government authorities) to be the basis for the economic development of innovative type (2000). We agree that establishing effective ties between the mentioned participants will allow setting up a creative environment in the country capable of generating new knowledge with the aim of their practical application in the industrial economic sector.

\section{Clusterization of administrative-territorial units of Ukraine}

According to Ukrainian scientists, cluster approach is an effective means of transition of industrial potential onto innovative development basis (Zhalila, 2014; Kulishov, 2013; Khmara, 2013). In addition, an innovative cluster gets a boost for the development due to the high innovative ability of cluster's participants (Mazniev, 2013). L. I. Fedulova points out that development of clusterization will promote technological development of industrial potential that will assure organization of much higher technological approaches in the national economy (2010).

Main obstacles, according to V. Heiets, on the way to the industrial development on the innovative basis are the following: lack of financing of fundamental 
and applied researches, shortage of skilled workforce, deterioration of investment climate in the country, low level of innovative infrastructure development, political and economic instability (2015). In addition, the scientist proves the necessity of establishing cooperation between the state, science, education, and enterprise structures with the aim to eliminate the development of negative tendencies.

In order to determine spatial features of the development of intellectual and innovative components, we suggest using indicators provided in the work (Kuzmin, Shpak \&Stanasiuk, 2017).

The system of indicators, which characterizes cluster's constituents, includes:

for evaluation of the development level of educational constituent:

- the share of students of higher educational establishments of I-IV levels of accreditation in the number of population, \%;

- number of higher educational establishments of I-IV levels of accreditation, units;

for evaluation of the development level of scientific constituent:

- ratio of researchers in the number of economically active population, \%;

- number of scientific organizations, units;

- the share of scientific and scientific-technical works in gross regional product, \%;

for evaluation of the development level of innovative constituent:

- the share of industrial enterprises that introduce innovations, \%;

- the share of industrial enterprises that introduce market innovations, \%;

- technological innovativeness of industrial enterprises, units per 1 industrial enterprise;

- product innovativeness of industrial enterprises, units per 1 industrial enterprise;

- a number of industrial enterprises that supplied innovative products outside Ukraine, units.

The system of indicators was worked out taking into account possibilities of getting relevant statistic data from the website of the State Statistics Service of Ukraine.

The research was carried out in 25 administrativeterritorial units of Ukraine by means of the indistinct $S$-averages method that provides the best results under the condition of the vagueness of information.

Regarding that $S$ value is determined by an expert method; we suggest distinguishing four clusters regarding the development levels of certain constituents (very high, high, average, and low).

Each administrative territorial unit, to a certain extent (from 0 to 1 ), belongs to a certain cluster. None of the clusters can contain all elements or, vice versa, be empty.

The following matrix, built with the formula (Taraskina, 2013), is used to define the final result:

$$
M=\left[\begin{array}{cccc}
m_{11} & m_{12} & \ldots & m_{1 l} \\
m_{21} & m_{22} & \ldots & m_{2 l} \\
\ldots & \ldots & \ldots & \ldots \\
m_{c 1} & m_{c 2} & \ldots & m_{c l}
\end{array}\right],
$$

where: $M$ - a matrix of the degree of belonging, $m_{i j}$ degree of belonging of $j$ administrative-territorial unit to $i$ cluster.

The results of non-distinct clusterization of administrative-territorial units of Ukraine by the indexes of intellectual constituent development are shown in Table 1.

Taking into account the indexes of development of academic and scientific constituents, the biggest cluster is the third one, which comprises 16 administrativeterritorial units. Administrative-territorial units belonging to the first cluster (Dnipropetrovsk, Lviv, Odesa, and Kharkiv regions) concentrate basic relative share of academic and scientific establishments of Ukraine.

However, the inner structure of the cluster is too complex because the degree of belonging of regions ranges from 0,35 (Kharkiv region) to 0,90 (Dnipropetrovsk region) that explains the high degree of variation of other indexes.

The same situation is observed in the fourth cluster, which consists of Zaporizhzhia, Mykolaiv, Sumy, and Chernivtsi regions that are characterized by far lower indexes of intellectual constituent development.

The most favourable conditions for accumulation of the intellectual potential are in the city of Kyiv, which is the leader by indexes of development of both academic and scientific constituents.

Specific indexes were used to study the innovative constituent that allowed analysing the product, technological and market innovativeness of industrial enterprises, as well as the level of innovations transfer (Table 2).

It's worth mentioning that the first cluster is the biggest by size on a quantitative criterion and administrativeterritorial units that it consists of concentrate the bulk of innovatively active industrial enterprises.

Administrative-territorial units characterized by the high level of innovations transfer are the part of the fourth cluster. Administrative-territorial units, which belong to the second cluster, are characterized by high indexes of market innovativeness. The lowest indexes of innovative activity are specific for administrativeterritorial units of the third cluster.

Administrative-territorial units of Ukraine were grouped by the levels of intellectual and innovative constituent's growth of the industrial potential in Table 3 .

The characteristic feature of intellectually-innovative clusters creation is that attention is focused not on the separate industrial enterprises but on establishing cooperation between research institutions and business structures. Such clusters are able to grow under the condition of a high frequency of ideas generating and existing possibilities of their implementation. 
Vol. 5, No. 1, 2019

Table 1

The matrix of belonging degree of spatial concentration of intellectual constituent to four clusters

\begin{tabular}{|c|c|c|c|c|c|c|c|c|}
\hline \multicolumn{4}{|c|}{ Number of a cluster } & \multirow{2}{*}{$\begin{array}{l}\text { Administrative- } \\
\text { territorial units }\end{array}$} & \multicolumn{4}{|c|}{ Number of a cluster } \\
\hline 1 & 2 & 3 & 4 & & 1 & 2 & 3 & 4 \\
\hline & & + & & Vinnytsia & 0,02 & 0,00 & 0,89 & 0,09 \\
\hline & & + & & Volyn & 0,01 & 0,00 & 0,94 & 0,05 \\
\hline \multirow[t]{9}{*}{+} & & & & Dnipropetrovsk & 0,90 & 0,01 & 0,04 & 0,06 \\
\hline & & + & & Donetsk & 0,07 & 0,00 & 0,70 & 0,23 \\
\hline & & + & & Zhytomyr & 0,01 & 0,00 & 0,95 & 0,04 \\
\hline & & + & & Zakarpattia & 0,02 & 0,00 & 0,88 & 0,10 \\
\hline & & & + & Zaporizhzhia & 0,19 & 0,01 & 0,13 & 0,67 \\
\hline & & + & & Ivano-Frankivsk & 0,01 & 0,00 & 0,96 & 0,03 \\
\hline & & + & & Kyiv & 0,05 & 0,00 & 0,66 & 0,28 \\
\hline & & + & & Kirovohrad & 0,02 & 0,00 & 0,87 & 0,11 \\
\hline & & + & & Luhansk & 0,04 & 0,00 & 0,78 & 0,18 \\
\hline \multirow[t]{2}{*}{+} & & & & Lviv & 0,74 & 0,01 & 0,10 & 0,15 \\
\hline & & & + & Mykolaiv & 0,17 & 0,01 & 0,18 & 0,63 \\
\hline \multirow[t]{5}{*}{+} & & & & Odesa & 0,52 & 0,01 & 0,20 & 0,27 \\
\hline & & + & & Poltava & 0,03 & 0,00 & 0,84 & 0,13 \\
\hline & & + & & Rivne & 0,02 & 0,00 & 0,88 & 0,10 \\
\hline & & & + & Sumy & 0,03 & 0,00 & 0,19 & 0,78 \\
\hline & & + & & Ternopil & 0,04 & 0,00 & 0,77 & 0,19 \\
\hline \multirow[t]{7}{*}{+} & & & & Kharkiv & 0,35 & 0,30 & 0,15 & 0,20 \\
\hline & & + & & Kherson & 0,00 & 0,00 & 0,97 & 0,03 \\
\hline & & + & & Khmelnytskyi & 0,01 & 0,00 & 0,95 & 0,04 \\
\hline & & + & & Cherkasy & 0,03 & 0,00 & 0,64 & 0,33 \\
\hline & & & + & Chernivtsi & 0,01 & 0,00 & 0,08 & 0,91 \\
\hline & & + & & Chernihiv & 0,01 & 0,00 & 0,95 & 0,05 \\
\hline & + & & & Kyiv (city) & 0,00 & 0,99 & 0,00 & 0,00 \\
\hline
\end{tabular}

Calculated by the authors according to source: Vidkryta statystychna baza Derzhavnoi sluzhby statystyky Ukrainy

Table 2

The matrix of belonging degree of spatial concentration of innovative constituent to four clusters

\begin{tabular}{|c|c|c|c|c|c|c|c|c|}
\hline \multicolumn{4}{|c|}{ Number of a cluster } & \multirow{2}{*}{$\begin{array}{l}\text { Administrative- } \\
\text { territorial units }\end{array}$} & \multicolumn{4}{|c|}{ Number of a cluster } \\
\hline 1 & 2 & 3 & 4 & & 1 & 2 & 3 & 4 \\
\hline & & + & & Vinnytsia & 0,07 & 0,03 & 0,84 & 0,06 \\
\hline & & & + & Volyn & 0,04 & 0,02 & 0,13 & 0,81 \\
\hline & & & + & Dnipropetrovsk & 0,03 & 0,02 & 0,12 & 0,82 \\
\hline & & & + & Donetsk & 0,06 & 0,05 & 0,17 & 0,72 \\
\hline & & + & & Zhytomyr & 0,09 & 0,04 & 0,72 & 0,15 \\
\hline & & & + & Zakarpattia & 0,16 & 0,15 & 0,28 & 0,41 \\
\hline & + & & & Zaporizhzhia & 0,19 & 0,71 & 0,07 & 0,03 \\
\hline \multirow[t]{2}{*}{+} & & & & Ivano-Frankivsk & 0,42 & 0,24 & 0,24 & 0,10 \\
\hline & & & + & Kyiv & 0,07 & 0,04 & 0,44 & 0,45 \\
\hline \multirow[t]{2}{*}{+} & & & & Kirovohrad & 0,61 & 0,25 & 0,10 & 0,04 \\
\hline & & & + & Luhansk & 0,09 & 0,07 & 0,21 & 0,62 \\
\hline+ & & & & Lviv & 0,42 & 0,15 & 0,36 & 0,08 \\
\hline \multirow[t]{5}{*}{+} & & & & Mykolaiv & 0,50 & 0,29 & 0,15 & 0,07 \\
\hline & & + & & Odesa & 0,21 & 0,08 & 0,59 & 0,11 \\
\hline & & + & & Poltava & 0,30 & 0,22 & 0,37 & 0,11 \\
\hline & & & + & Rivne & 0,03 & 0,02 & 0,13 & 0,82 \\
\hline & + & & & Sumy & 0,25 & 0,43 & 0,18 & 0,14 \\
\hline \multirow[t]{4}{*}{+} & & & & Ternopil & 0,29 & 0,28 & 0,24 & 0,19 \\
\hline & + & & & Kharkiv & 0,30 & 0,55 & 0,10 & 0,05 \\
\hline & + & & & Kherson & 0,24 & 0,64 & 0,08 & 0,04 \\
\hline & & + & & Khmelnytskyi & 0,05 & 0,02 & 0,82 & 0,10 \\
\hline+ & & & & Cherkasy & 0,71 & 0,13 & 0,13 & 0,03 \\
\hline \multirow[t]{2}{*}{+} & & & & Chernivtsi & 0,72 & 0,11 & 0,13 & 0,04 \\
\hline & & + & & Chernihiv & 0,12 & 0,05 & 0,73 & 0,11 \\
\hline+ & & & & Kyiv (city) & 0,42 & 0,40 & 0,13 & 0,05 \\
\hline
\end{tabular}

Calculated by the authors according to source: Vidkryta statystychna baza Derzhavnoi sluzhby statystyky Ukrainy 
Table 3

Qualitative structure of clusters of the spatial collaboration of intellectual and innovative constituents of the industrial potential

\begin{tabular}{|c|l|l|l|l|}
\hline \multicolumn{1}{|c|}{ Cluster } & \multicolumn{1}{c|}{ Low } & \multicolumn{1}{c|}{ Average } & \multicolumn{1}{c|}{ High } & \multicolumn{1}{c|}{ Very high } \\
\cline { 1 - 3 } $\begin{array}{l}\text { Intellectual } \\
\text { constituent }\end{array}$ & $\begin{array}{l}\text { Vinnytsia, Volyn, Donetsk, } \\
\text { Zhytomyr, Zakarpattia, Ivano- } \\
\text { Frankivsk, Kyiv, Kirovohrad, } \\
\text { Luhansk, Poltava, Rivne, Ternopil, } \\
\text { Kherson, Khmelnytskyi, Cherkasy, } \\
\text { Chernihiv regions }\end{array}$ & $\begin{array}{l}\text { Zaporizhzhia, Mykolaiv, } \\
\text { Sumy, Chernivtsi regions }\end{array}$ & $\begin{array}{l}\text { Dnipropetrovsk, Lviv, } \\
\text { Odesa, Kharkiv regions }\end{array}$ & The city of Kyiv \\
\hline $\begin{array}{l}\text { Innovative } \\
\text { constituent }\end{array}$ & $\begin{array}{l}\text { Vinnytsia, Zhytomyr, Odesa, } \\
\text { Poltava, Khmelnytskyi, Chernihiv } \\
\text { regions }\end{array}$ & $\begin{array}{l}\text { Volyn, Dnipropetrovsk, } \\
\text { Donetsk, Zakarpattia, } \\
\text { Kyiv, Luhansk, Rivne } \\
\text { regions }\end{array}$ & $\begin{array}{l}\text { Zaporizhzhia, Sumy, } \\
\text { Kharkiv, Kherson regions }\end{array}$ & $\begin{array}{l}\text { Ivano-Frankivsk, Kykolaiv, Ternopil, } \\
\text { Cherkasy, Chernivtsi regions, } \\
\text { and the city of Kyiv }\end{array}$ \\
\hline
\end{tabular}

Source: composed by the authors

Otherwise, a cluster will lose its reproductive ability, that is, creative environment acts as a cluster creation core. Taking into account the achieved results, Dnipropetrovsk, Lviv, Odesa, Kharkiv regions, and Kyiv can become such centres in Ukraine. This fact gives the opportunity to talk about the possibility of the creation of five intellectually-innovative clusters capable of concentrating innovatively active industrial enterprises around themselves.

Today, the most dynamic innovative development of industrial potential is observed in Lviv, Kharkiv regions and Kyiv with high indexes of development of both intellectual and innovative components. The most negative situation is observed in the Odesa region that proves the necessity to establish cooperation between scientific institutions, academic establishments, and business entities.

The emergence of similar contradictions in other administrative-territorial units points to the necessity of involving the state to act as an activator of the innovative process and as a regulator of establishing collaboration.

\section{Formation of conceptual principles of intellectually-innovative industrial clusters creation}

We believe that, first of all, it is necessary to adopt the Conception of cluster policy in order to do systematization of clusterization processes in Ukraine. It should contain not only aims, tasks, priorities, and directions but also foresee the introduction of pilot projects of implementation of the actions of cluster policy on both state and regional levels. For this purpose, the state, first of all, should work out the program of pilot clusters on the central level to list territorial clusters (on competitive principles), which are the most significant for the state. Taking into account the necessity of technological development of industrial potential, innovative industrial clusters must be organized by the following types of industrial activity: production of computers, electronic and optical products; production of electric equipment; production of chemicals and chemical products; production of basic pharmaceutical products and medication.

Inordertomakeindustrialproduction environmentally friendly, it is useful to introduce projects related to the introduction of the resource and energy saving technologies, and low-waste manufacturing plants.

According to S. Y. Glazev, the development of microelectronics, biotechnologies, genic engineering, robot technology, nano- and picotechnologies, systems of artificial intelligence, as well as systems of high-speed transportation, and space exploration will promote the development of higher technological structures in the national economy (1990).

A set of certain actions should become inseparable as to the state support of industrial potential development on a cluster basis. They should include stimulation of participation of large enterprises in clusters structure, granting some tax deductions (taking into account the assessment of the productive and innovative potential of territorial clusters), providing target-oriented grants to local budgets (under the condition of co-financing of clusters from regional budgets) and others.

We should note that basic forms of stimulation of small innovative enterprises including cluster industrial systems were developed long ago in the world practice (Figure 1).

Alongside scientific research and educational establishments and organizations, intellectual and innovative clusters must include such participants:

$\checkmark$ enterprises and organizations that take a direct part in production and distribution of the ready-made goods or services, suppliers of goods or services;

$\checkmark$ enterprises and organizations that compose infrastructure of production and distribution of the ready-made goods or services;

$\checkmark$ organizations of market infrastructure (auditing, consulting, crediting, insurance and lease services, logistic, trade, business with real property); 
$\checkmark$ organizations of innovative infrastructure (business-incubators, techno parks, industrial parks, regional centres of innovative development);

$\checkmark$ organizations to support the development of small and middle business infrastructure (venture funds; centres for technology transfer; centres and agencies for entrepreneurship growth, regional development, attracting investments; native financial institutions; agencies for commodities export support; funds of entrepreneurship support; funds of crediting assistance, investment funds, closed stock investment funds which attract investments for small and middle business entities, etc.).

The form "Cluster Passport" is offered to use in order to institutionalize the activity of cluster creation, which should contain the following information: the name of the cluster; initiators of the project of cluster creation; regulatory assurance of cluster activity (standards

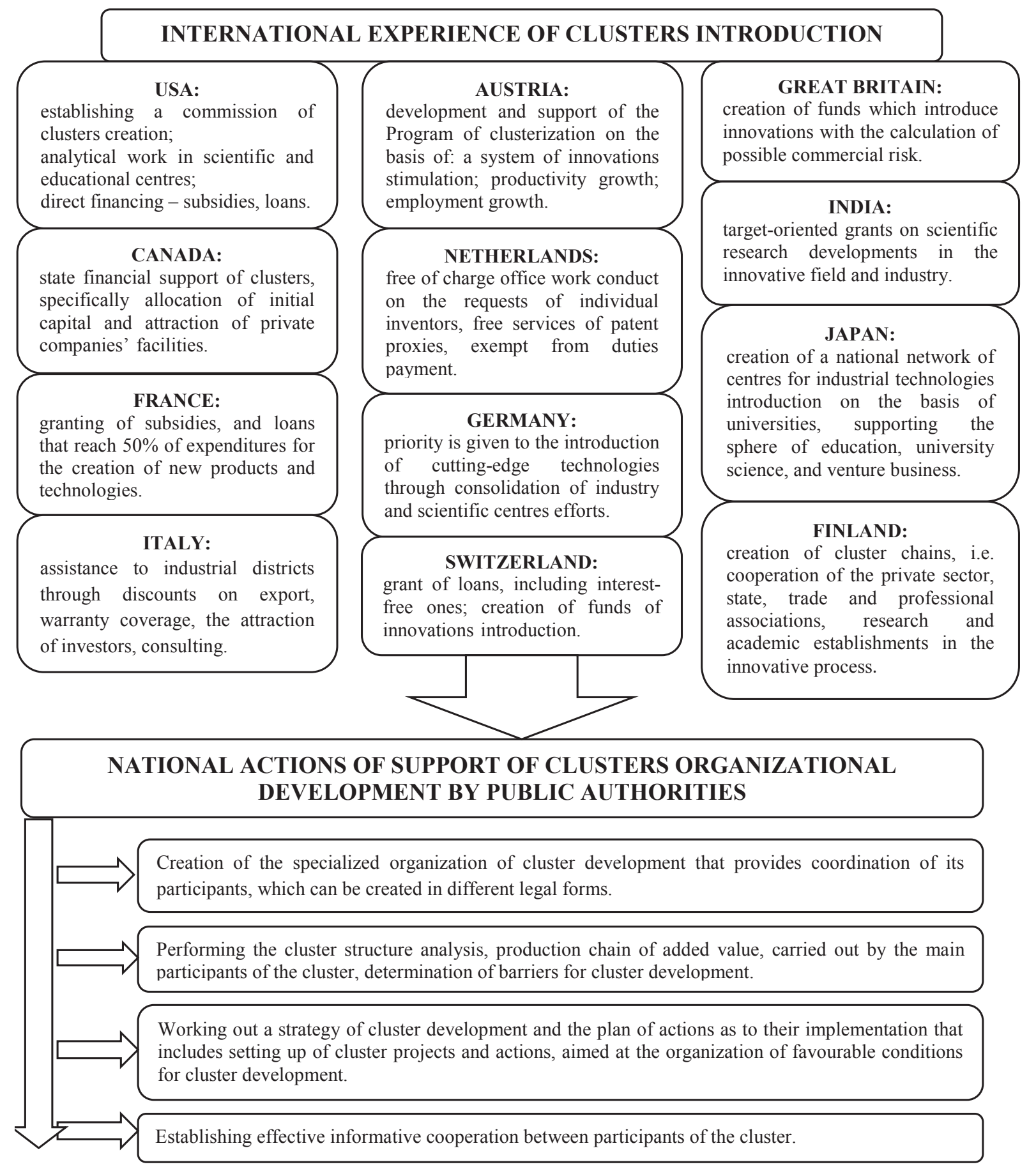

Figure 1. Introduction of the world practice of stimulation of industrial potential development on a cluster basis

Source: summarized by the authors (Kastels \& Khimanen, 2006; Khomych, 2007; Chykarenko \& Mamatova, 2011) 
and regulations); definition of cluster missions and its visions (cluster conception); cluster participants (legal/natural entities) and their voluntarily obligations; management staff of the cluster (council or core of the cluster); expected results of the activity (short-term and long-term); target (address) groups that "experience" the results of cluster activity; stages of cluster creation (name of the stage, responsibility, terms of implementation); necessary resources (material, technical, financial, human, intellectual, and others); potential risks (internal and external) and ways of their prevention (overcoming or reduction of influence); cluster stakeholders (to carry out external control and represent interests of the cluster on all levels) (Sharov \& Chykarenko, 2012). We recommend adding the following blocks: project innovativeness (product, technological or market) and relevance to the strategic priorities of economic development (of states, regions, etc.).

It is necessary to note that the creation of innovative clusters can also take place by the cost of state and local budgets. In this case, financial mechanism of state support of implementation of wide range of cluster projects must be quite flexible and involve several directions, for example: development of transportation, energy, and engineering infrastructure; development of housing and social infrastructure, including of material and technical base for health protection, culture and sport; development ofinnovative and educational infrastructure, implementation of works and projects in the field of research and developments, carrying out innovative activity, training and upgrading employees' qualification; taking other actions in order to increase competitiveness of not only the organizations-participants of a cluster but also the territory of cluster location, and to rise the life quality of territorial communities.

\section{Conclusions}

Summarizing the achieved results, we state the following:

1. Taking into account foreign experience, establishing collaboration between a research sphere and business structures is an essential stimulator for innovative development of the industrial potential. The leading role in a cluster network belongs to research institutions and educational establishments, which role is to develop and invent an innovative product that meets market requirements and priorities of the economic policy of the state.

2 . Keeping in mind the results of administrativeterritorial units' clusterization in Ukraine, we offer to distinguish five intellectually-innovative clusters by the indexes of intellectual (centres for knowledge resources) and innovative constituents' development (the economic basis of a cluster) with cluster formation centres in Kyiv, Dnipropetrovsk, Lviv, Odesa, and Kharkiv regions. Creation of intellectuallyinnovative industrial clusters will assist the effective use of knowledge, the increase of intellectual labour efficiency, and application of its results for the transition of industrial potential onto the innovative development basis.

3. Considerable spatial asymmetry on the levels of development of intellectual and innovative constituents underlines the necessity of involving the state as a regulator and stimulator for establishing partnership relations, as well as an activator of innovative processes in the state. Provision of state support for pilot projects realization aimed at hi-tech productions development will allow increasing the competitiveness of the national industrial potential and national economy in particular.

\section{References:}

Bloomberg Innovation Index (n.d.) Retrieved from: https://www.bloomberg.com.

Chykarenko, I., Mamatova, T. (2011). Proektnyi ta klasternyi pidkhody v zabezpechenni innovatsiinoho rozvytku mista [Project and cluster approaches in providing innovative city development]. Derzhavne upravlinnia ta mistseve samovriaduvannia, 3(10), 238-247. (in Ukrainian)

Druhov, O. O. (2012). Perspektyvy stvorennia intelektualno-innovatsinykh klasteriv v ekonomitsi Ukrainy [Perspectives of creation of intellectual-innovative clusters in the economy of Ukraine]. Rehionalna ekonomika, 1, 31-37. (in Ukrainian)

Etzkowitz, H., Leydesdorff, L. (2000). The dynamics of innovation: from national systems and "Mode 2" to a triple helix university-industry-government relations. Research Policy, 29, 109-123.

Fedulova, L. I. (2010). Metodolohichni zasady formuvannia tekhnolohichnykh klasteriv [Methodological principles of formation of technological clusters]. Ekonomika i prohnozuvannia, 3, 61-73. (in Ukrainian)

Glazev, S. Iu. (1990). Ekonomicheskaia teoriia tekhnichnogo razvitiia [The economic theory of technical development]. Moskva: Nauka. (in Russian)

Heiets, V. M. (2015). Bariery na shliakhu rozvytku promyslovosti na innovatsiinii osnovi ta mozhlyvosti yikh podolannia [Barriers to the development of industry on an innovative basis and the possibilities of overcoming them]. Ekonomika Ukrainy, 1, 4-25. (in Ukrainian)

Kastels, M. \& Khimanen, P. (2006). Informatsiine suspilstvo ta derzhava dobrobutu. Finska model [Information society and the state of welfare. Finnish model]. (Trans.). Kyiv: Vakler. (in Ukrainian)

Khmara, M. (2013). Klasternyi pidkhid u stratehii innovatsiinoho rozvytku zarubizhnykh krain [Cluster approach in the strategy of innovative development of foreign countries]. Visnyk Kyivskoho natsionalnoho universytetu imeni Tarasa Shevchenka. Mizhnarodni vidnosyny, 1, 51-53. (in Ukrainian) 
Khomych, L. V. (2007). Stratehiia rehionalnoho rozvytku i planuvannia terytorii [Regional development strategy and territorial planning]. Stratehichni priorytety, 4(5). (in Ukrainian)

Kulishov, V. V. (2013). Klaster - osnova innovatsiinoho rozvytku ekonomiky [The cluster is the basis of innovative economic development]. Innovatsiina ekonomika, 2, 3-6. (in Ukrainian)

Kuzmin, O., Shpak, N. \& Stanasiuk, N. (2017). Innovation clusters as an important factor providing industrial potential. Econtechmod: an international quarterly journal on economics in technology, new technologies and modelling processes, 6(1), 71-80.

Mansfield, E. (1998). Academic research and industrial innovation: an update of empirical finding. Research Policy, 26(7-8), 773-776.

Marshall, A. (2008). Printcipy politicheskoi ekonomii [Principles of political economy]. Moskva: Direktmedia Pablishing. (in Russian)

Mazniev, H. (2013). Innovatsiini tekhnolohichni klastery [Innovative technological clusters]. Ekonomika APK, 8, 63-67. (in Ukrainian)

Porter, M. E. (1990). The competitive advantage of nations. New York: Free Press.

Sharov, Yu., Chykarenko, I. (2012). Instytutsiino-orhanizatsiini aspekty stvorennia munitsypalnykh klasteriv [Institutional and organizational aspects of the creation of municipal clusters]. Derzhavne upravlinnia ta mistseve samovriaduvannia, 1(12), 179-191. (in Ukrainian)

Taraskina, A. S. (2013). Nechetkaia klasterizatciia po modifitcirovannomu metodu S-srednikh i ee primenenie dlia obrabotki mikrochipovykh dannykh [Fuzzy clustering using the modified C-averages method and its application for microchip data processing]. Problemy intellektualizatcii $i$ kachestva sistem avtomatizatcii, 13, 217-228. (in Russian)

Vidkryta statystychna baza Derzhavnoi sluzhby statystyky Ukrainy [The statistical base of the State Statistics Service of Ukraine is open] (n.d.). Retrieved from: http://www.ukrstat.gov.ua (in Ukrainian)

Zhalila, Ya. A. (Ed.) (2014). Innovatsiinyi rozvytok promyslovosti yak skladova strukturnoi transformatsii ekonomiky Ukrainy [Innovative development of industry as a component of the structural transformation of the Ukrainian economy]. Kyiv: NISD. (in Ukrainian) 